Gazi University
Pournal of Science
PART C: DESIGN AND TECHNOLOGY
http://dergipark.gov.tr/gujsc

\title{
Investigation of the Effect of Using Fe + Pure Water Nanofluid on Thermal Performance in a Two Phase Closed Thermosyphon
}

\author{
Kerim MARTIN (D) \\ Kahraman Maraş Istiklal University, Elbistan Engineerig Faculty, Department of Energy Systmes Engineering, 46300, \\ Elbistan/KAHRAMANMARAŞ
}

\section{Article Info}

Research article

Received:05/05/2021

Revision:28/05/2021

Accepted:29/05/2021

\section{Keywords}

Heat Pipe

Nano Fluid

Thermal Performance

Waste Heat

\begin{abstract}
Heat is a type of energy that is used in many applications and can be easily converted into other types of energy. In this study, a performance analysis was carried out by using $\mathrm{Fe}+$ Pure water nanofluid in place of pure water in a two phase closed thermosyphon, which has a wide place in practice due to its simple structure. In the study, a copper thermosyphon with a length of $1 \mathrm{~m}$, diameter of $14 \mathrm{~mm}$ and wall thickness of $1 \mathrm{~mm}$ was used. Experiments were performed with both pure water and nanofluid to make a comparison. To observe the performance of system in different operating conditions, the experiments were carried out at 3 different heating power $(150,300,450 \mathrm{~W})$ and 3 different coolant flow rates $(3,6,9 \mathrm{~g} / \mathrm{s})$. In all experimental conditions, $\mathrm{Fe}+$ Pure water nanofluid had better results than pure water. The highest efficiency value was found to be $77.9 \%$ in the experiment using $\mathrm{Fe}+$ Pure water nanofluid, performed at $150 \mathrm{~W}$ power and $9 \mathrm{~g} / \mathrm{s}$ water flow rate. When pure water was used in this experiment, the efficiency value was obtained as $67.7 \%$ and the improvement rate was $15 \%$. The highest improvement rate was obtained as $50.3 \%$ in the experiment conducted at $450 \mathrm{~W}$ heating power and $3 \mathrm{~g} / \mathrm{s} \mathrm{coolant}$ flow rate. The use of nanofluid has also reduced the thermal resistance of the thermosyphon. The highest rate of decrease in thermal resistances was obtained as $56.7 \%$ in the experiment performed at $150 \mathrm{~W}$ heating power and $3 \mathrm{~g} / \mathrm{s}$ coolant flow rate.
\end{abstract}

\section{INTRODUCTION}

Heat energy which is one of the most common types of energy, can be easily converted into other forms of energy thanks to energy conversion methods. Heat energy is primarily produced from fossil fuels which meet $80 \%$ of the primary energy demand in the world [1]. However, heat is a type of energy that is easily lost and a considerable amount of waste heat is generated in thermal processes.

It is estimated that $63 \%$ of the primary energy consumption on a global basis is realized during the combustion and heat transfer processes. This consumption is generally defined as waste heat and needs to be recovered [2]. Considering that in addition to the carbon emission made to the environment during the production of heat, the vast majority of the waste heat generated during its use is also released to the environment, it can be seen how much the damage to the environment is. States set some policies and goals to deal with these harms. For example, 20\% energy efficiency, 20\% greenhouse gas emission reduction and $20 \%$ renewable energy targets for 2020, which were determined by the European Union as 20-20-20 for the previous years, have been updated for the year 2030 as $32.5 \%, 40 \%$ and $32 \%$ respectively [3].

Here, one of the applications that can be done in terms of ensuring energy efficiency and that can get results in the short term is waste heat recovery. Significant energy savings can be achieved by installing simple and low-cost heat exchangers. One of these heat exchangers is the heat pipes, which are very attractive in terms of their simple structure and application flexibility. Heat pipes are simple heat exchangers that provide mass and heat transfer with the phase change of the working fluid inside and consist of three parts: evaporator, adiabatic zone and condenser. 
There are several kinds of heat pipes which are used in different researches and applications. In thermosyphons, the fluid evaporates by gaining energy in the evaporator side. The fluid condenses by losing heat in the condenser side and turns to the evaporator section by means of gravity. Whereas there are wicks in conventional heat pipes, there is no wick in thermosyphons. In addition to conventional heat transfer fluids in heat pipes, various nanofluids are also frequently used to improve thermal performance. Some of the recent studies on this topic are given in Table 1.

Table 1: Some studies about heat pipe application in literature

\begin{tabular}{|c|c|c|c|c|c|}
\hline Author & Year & $\begin{array}{c}\text { Heat Pipe } \\
\text { Type }\end{array}$ & $\begin{array}{c}\text { Nano } \\
\text { Particle }\end{array}$ & $\begin{array}{l}\text { Base } \\
\text { Fluid }\end{array}$ & Results \\
\hline $\begin{array}{l}\text { Ahmet } \\
\text { Özsoy and } \\
\text { Vahit } \\
\text { Çorumlu } \\
\text { [4] }\end{array}$ & 2018 & Thermosyphon & Ag & $\begin{array}{l}\text { Pure } \\
\text { Water }\end{array}$ & $\begin{array}{l}\text { The use of nanofluids has improved the heat } \\
\text { transfer characteristics of the heat pipe. } \\
\text { Researchers have achieved improvements ranging } \\
\text { from } 20.7 \% \text { to } 40 \% \text { when compared with pure } \\
\text { water. }\end{array}$ \\
\hline $\begin{array}{l}\text { Metin Kaya } \\
\text { et al. [5] }\end{array}$ & 2019 & $\begin{array}{l}\text { Vacuum Tube } \\
\text { Heat Pipe Air } \\
\text { Collector }\end{array}$ & $\mathrm{CuO}$ & Methanol & $\begin{array}{l}\text { Experimental studies have shown that nanofluid } \\
\text { usage improve the thermal performance and } \\
\text { nanofluids can be used in heat pipes. In addition, } \\
\text { it has been observed that CuO nanofluid is more } \\
\text { effective in this system when there is high solar } \\
\text { radiation. }\end{array}$ \\
\hline $\begin{array}{l}\text { Erdem } \\
\text { Çiftçi [6] }\end{array}$ & 2020 & $\begin{array}{l}\text { Two Phase } \\
\text { Closed } \\
\text { Thermosyphon }\end{array}$ & AlN & $\begin{array}{l}\text { Pure } \\
\text { Water }\end{array}$ & $\begin{array}{l}\text { The use of nanofluids in place of water has } \\
\text { improved the thermal performance of the heat } \\
\text { pipe. A decrease of } 10.9 \% \text { in thermal resistances } \\
\text { and an increase of } 45.6 \% \text { in efficiency were } \\
\text { achieved. }\end{array}$ \\
\hline $\begin{array}{l}\text { Wei-Wei } \\
\text { Wang et al. } \\
\text { [7] }\end{array}$ & 2020 & $\begin{array}{l}\text { Two Phase } \\
\text { Closed } \\
\text { Thermosyphon } \\
\text { Solar Collector }\end{array}$ & $\begin{array}{c}\mathrm{Cu}, \\
\mathrm{Fe} 2 \mathrm{O} 3 \\
\mathrm{Al} 2 \mathrm{O} 3\end{array}$ & $\begin{array}{l}\text { Pure } \\
\text { Water }\end{array}$ & $\begin{array}{l}\text { In the study, a unique model has been developed } \\
\text { to observe the effect of nanoparticles on the } \\
\text { thermal performance of the system. In the analysis } \\
\text { made with this model, the experimental data were } \\
\text { approached with deviations not greater than } 10 \% \text {. } \\
\text { According to the results, } 41 \%, 32 \% \text { and } 29 \% \\
\text { improvement was achieved by using nanofluids in } \\
\text { place of pure water. }\end{array}$ \\
\hline $\begin{array}{l}\text { Ebrahim } \\
\text { Khajehpour } \\
\text { et al. [8] }\end{array}$ & 2020 & $\begin{array}{c}\text { L-Shaped } \\
\text { Thermosyphon }\end{array}$ & $\mathrm{SiO} 2$ & $\begin{array}{l}\text { Pure } \\
\text { Water }\end{array}$ & $\begin{array}{l}\text { Usage of nanofluid has been analyzed how it } \\
\text { affected the thermal resistance of heat } \\
\text { pipe.Experiments were conducted with two } \\
\text { different particle sizes and two different particle } \\
\text { concentrations. With the use of nanofluid, heat } \\
\text { pipe thermal resistance has been reduced by a } \\
\text { maximum of } 24 \% \text {. }\end{array}$ \\
\hline
\end{tabular}


Table 1 (Continuous): Some studies about heat pipe application in literature

\begin{tabular}{|c|c|c|c|c|c|}
\hline $\begin{array}{l}\text { Anderson } \\
\text { Gallego et } \\
\text { al. [9] }\end{array}$ & 2020 & $\begin{array}{c}\text { Two Phase } \\
\text { Closed } \\
\text { Thermosyp } \\
\text { hon }\end{array}$ & $\mathrm{Al} 2 \mathrm{O} 3$ & $\begin{array}{l}\text { Pure } \\
\text { Water }\end{array}$ & $\begin{array}{l}\text { In this experimental study, different } \\
\text { concentrations of nanofluids were used. In } \\
\text { addition, experiments were carried out at } \\
\text { different filling ratios and power inputs. A } \\
\text { maximum increase of } 14.8 \% \text { in efficiency was } \\
\text { achieved. }\end{array}$ \\
\hline $\begin{array}{l}\text { Vidhya et } \\
\text { al. [10] }\end{array}$ & 2020 & Heat Pipe & $\mathrm{ZnO}, \mathrm{MgO}$ & $\begin{array}{c}\text { Pure } \\
\text { Water, } \\
\text { Ethylene } \\
\text { Glycol }\end{array}$ & $\begin{array}{l}\text { Hybrid nanofluid was prepared with two } \\
\text { different base fluids by using } 50: 50 \text { ratio of } \\
\text { nanoparticles. It has been observed that } \\
\text { nanoparticles improve the thermophysical } \\
\text { properties of base fluids. Compared to base } \\
\text { fluids, thermal resistances have been reduced } \\
\text { up to } 4.07 \% \text { and efficiency has been increased } \\
\text { up to } 28.9 \% \text {. }\end{array}$ \\
\hline $\begin{array}{l}\text { Arun } \\
\text { Kurien } \\
\text { Reji et al. } \\
{[11]}\end{array}$ & 2020 & $\begin{array}{l}\text { Two Phase } \\
\text { Closed } \\
\text { Thermosyp } \\
\text { hon }\end{array}$ & $\mathrm{Al} 2 \mathrm{O} 3$ & $\begin{array}{l}\text { Pure } \\
\text { Water }\end{array}$ & $\begin{array}{l}\text { Experiments were carried out with nanofluid } \\
\text { and pure water. Nanoparticle concentration } \\
\text { was } 1 \% \text { and power inputs varied between } 40 \\
\text { and } 200 \mathrm{~W} \text {. In addition, experiments were } \\
\text { performed for different angles. According to } \\
\text { the results, a maximum improvement in } \\
\text { efficiency was achieved as } 41 \% \text {. }\end{array}$ \\
\hline $\begin{array}{l}\text { Alagappan. } \\
\text { N et al. } \\
\text { [12] }\end{array}$ & 2020 & $\begin{array}{c}\text { Two Phase } \\
\text { Closed } \\
\text { Thermosyp } \\
\text { hon }\end{array}$ & $\begin{array}{l}\mathrm{CeO} 2, \\
\mathrm{Fe} 3 \mathrm{O} 4\end{array}$ & $\begin{array}{l}\text { Pure } \\
\text { Water }\end{array}$ & $\begin{array}{l}\text { In this study, it has been investigated how the } \\
\text { thermal performance of two phase closed } \\
\text { thermosyphon is affected by nanofluids. } \\
\text { Improvements in thermal performance have } \\
\text { been achieved with the usage of nanofluids. } \\
\text { When using Fe3O4nanofluid, the average heat } \\
\text { transfer increased by } 44.3 \% \text {. }\end{array}$ \\
\hline $\begin{array}{l}\text { Adnan } \\
\text { Sözen et } \\
\text { al. [13] }\end{array}$ & 2021 & $\begin{array}{l}\text { Air-to-Air } \\
\text { Heat } \\
\text { Exchanger } \\
\text { with Two } \\
\text { Phase } \\
\text { Closed } \\
\text { Thermosyp } \\
\text { hon } \\
\end{array}$ & $\begin{array}{c}\text { Graphene } \\
\text { Nano } \\
\text { Platelet }\end{array}$ & $\begin{array}{l}\text { Pure } \\
\text { Water }\end{array}$ & $\begin{array}{l}\text { In this experimental study, experiments were } \\
\text { made at different air velocities and heating } \\
\text { powers in a heat pipe air-to-air heat } \\
\text { exchanger. The peak improvement ratio in } \\
\text { efficiency was } 87.7 \% \text {. In addition, maximum } \\
\text { decrement in thermal resistance was } 52.3 \% \\
\text { when compared with pure water. }\end{array}$ \\
\hline
\end{tabular}

\section{MATERIAL AND METHOD}

\subsection{Nano Particle Properties and Nanofluid Preparation Process}

The nanoparticles were purchased from the supplier company (Nanografi Nano Teknoloji A.Ş.) in powder form. The purity of $\mathrm{Fe}$ (iron) nanoparticles is $99.55 \%$, and the average particle size is $30-40 \mathrm{~nm}$. Density, thermal conductivity and specific heat of Fe nano particle are $7800 \mathrm{~kg} / \mathrm{m} 3,76.2 \mathrm{~W} / \mathrm{mK}$ and $440 \mathrm{~J} / \mathrm{kgK}$ respectively [14].

Iron nanoparticles have a high thermal conductivity value. In this way, it is promising in increasing efficiency in heat transfer applications. SEM image and particle size distribution graph of iron nanoparticles are given in figure 1 and figure 2, respectively. When looking at the SEM image in Figure 1 , it can be easily seen that the average size of the nanoparticles is less than $50 \mathrm{~nm}$. It can also be understood from this SEM image that the majority of the particles are circular in shape. 


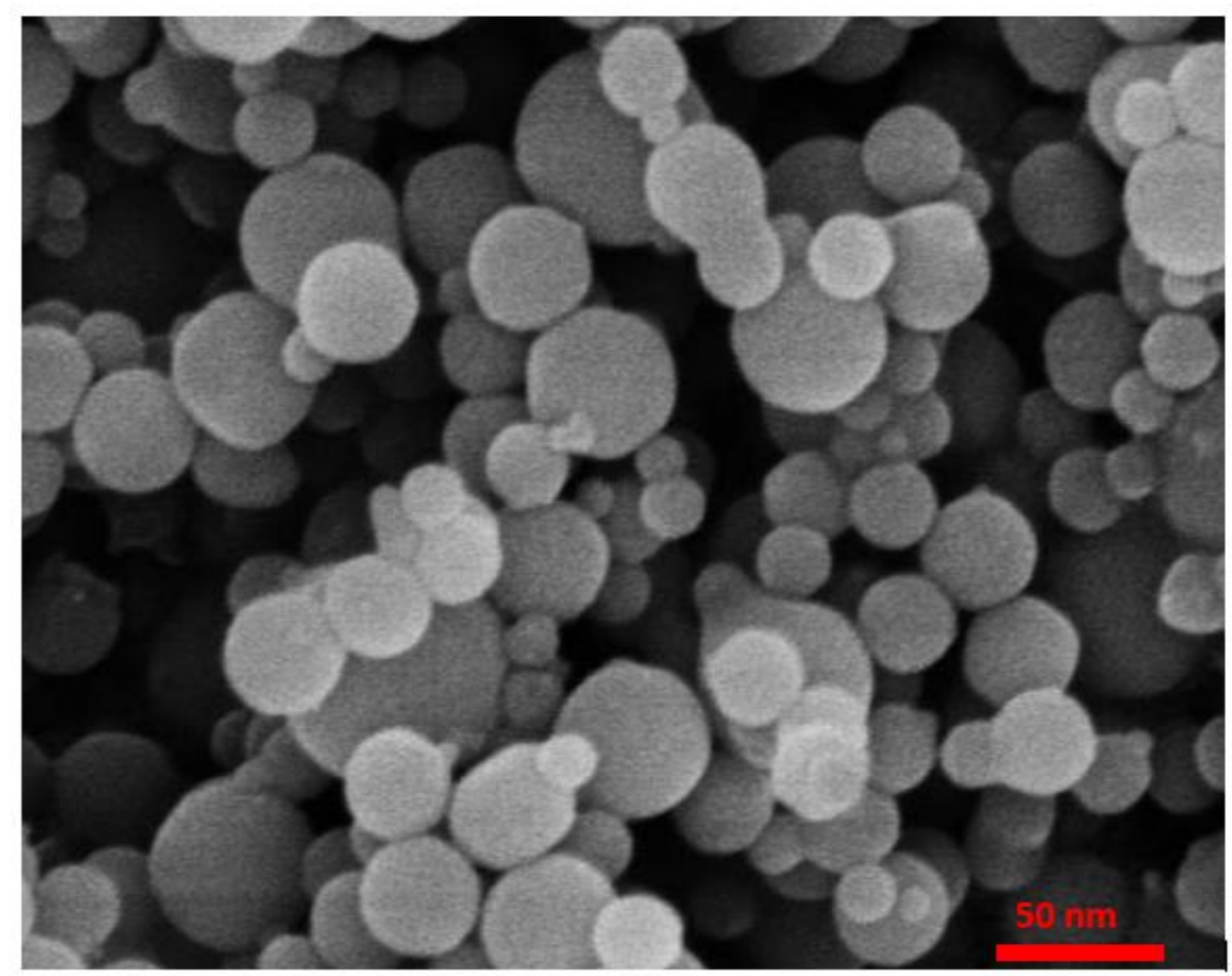

Figure 1: SEM image of the iron (Fe) nanoparticle [14]

In the graph in Figure 2, the blue line represents the \% fineness values on the left side and the red line represents the differential distribution values on the right side. Since the shapes of the nanoparticles are not completely round, the particle distributions are presented by creating different criteria. Here, the fineness value indicates how many percent of the particles are smaller than the specified size. For example, when moving from the $20 \%$ value in the left column to the right linearly up to the blue line, the particle size of approximately $27 \mathrm{~nm}$ is read from the horizontal column. This means that $20 \%$ of the particles are smaller than $27 \mathrm{~nm}$. For the same situation, it can be interpreted that $80 \%$ of the particles are larger than $27 \mathrm{~nm}$. The top of the red line represents the average particle size. In other words, it can be deduced from this scatter graph that the particles have an average size of $35 \mathrm{~nm}$. 


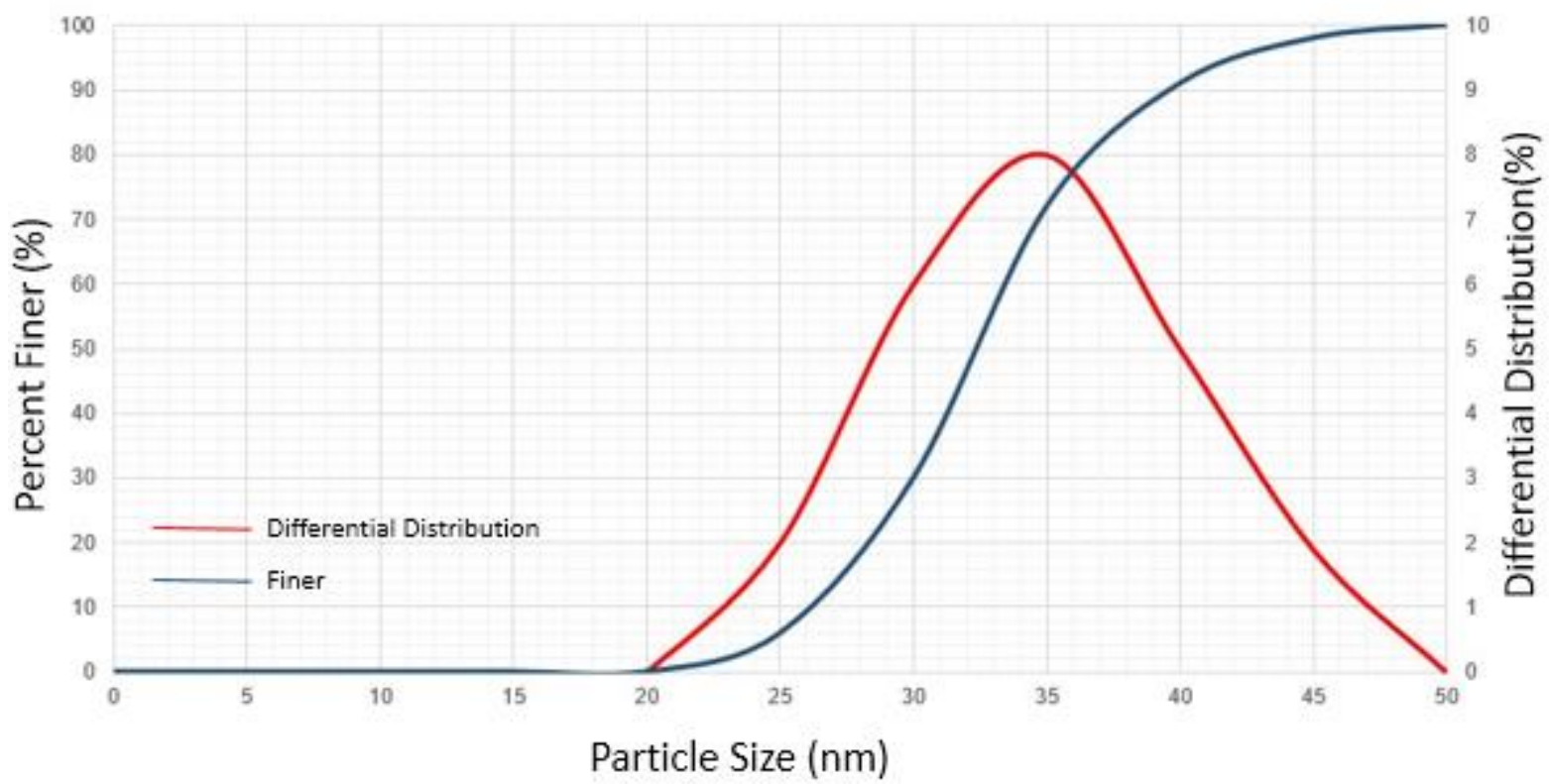

Figure 2: Particle size distribution graph of the Fe (Iron) nanoparticle [14]

There are two methods used to prepare nanofluids in the literature. First one is the one-step method in which the nanoparticle and the nanofluid are produced at the same time. The second method is two-step method in which the nanoparticle and nanofluid are produced in separate processes. The nanofluids used in the experiments were prepared using the two-step method. In this method, nanoparticles must have been produced beforehand. Then, the nanofluid is prepared by mixing the nanoparticles with a base fluid [15]. The nanofluid was prepared by suspending the Fe nanoparticles in pure water. The nanoparticle concentration was adjusted to be $1.5 \%$ by weight. Increasing the nanoparticle concentration increases the thermal performance of the fluid. However, high particle concentration causes some problems, especially the problem of sedimentation [16].

Adding surfactant to the mixture eliminates the problem of agglomeration and sedimentation [17]. For this purpose, Triton X-100 with the formula of $\mathrm{C} 14 \mathrm{H} 22 \mathrm{O}(\mathrm{C} 2 \mathrm{H} 4 \mathrm{O}) \mathrm{n}$ was put to the $\mathrm{Fe}+$ pure water mixture at the rate of $0.2 \%$ by weight. The mixture was subjected to ultrasonic vibration for 5 hours as a final treatment. The aim here is to distribute the nanoparticles homogeneously in the main fluid. Summary of nanofluid preparation process is shown in fig 3. The pictures of nano particles and nanofluid are shown in fig.4.

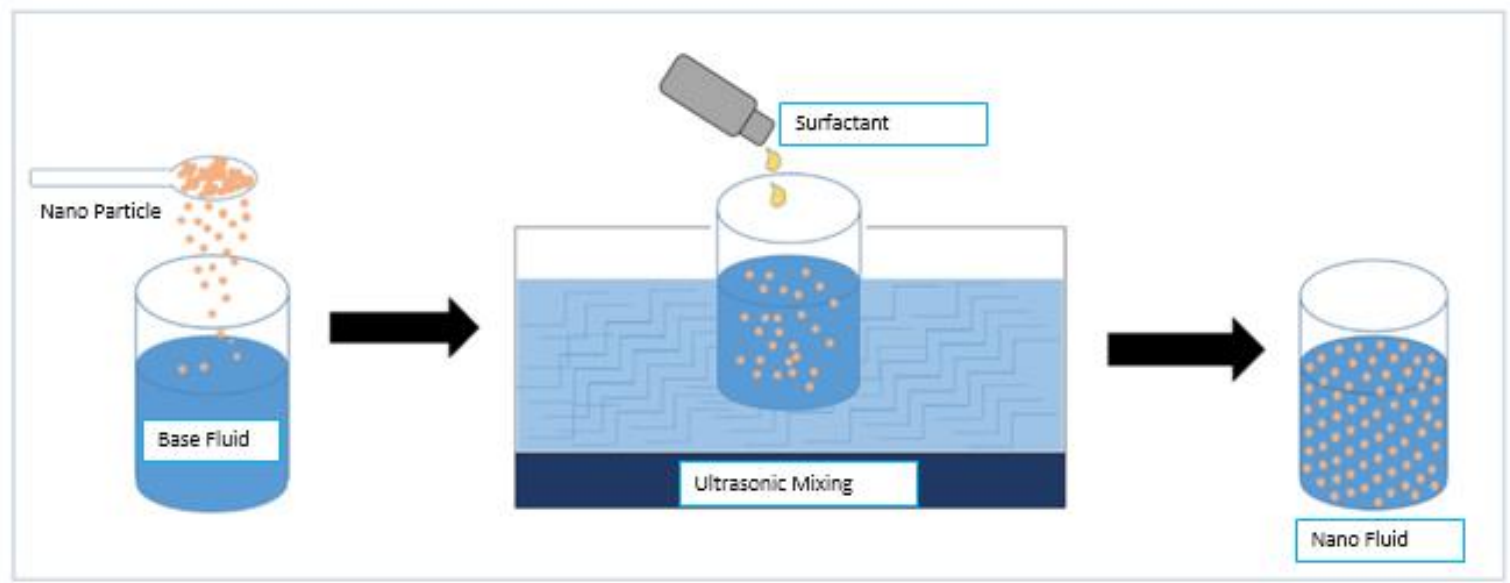

Figure 3: Nanofluid preparation process [18] 

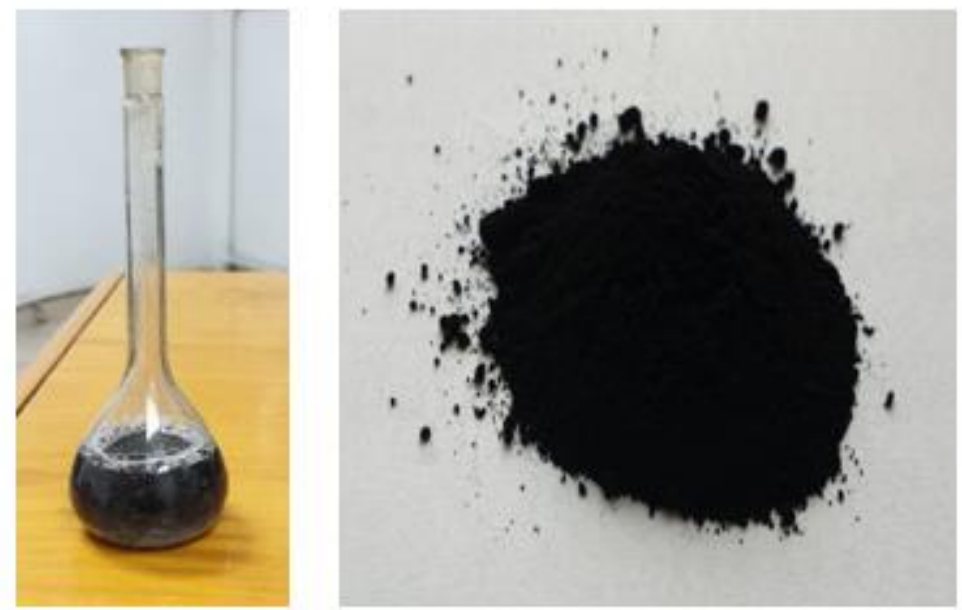

Figure 4: Nanofluid and nano particle

\subsection{Experimental Setup}

The test rig consists of a closed tube without wick. It is made of copper. Its wall thickness, diameter and length are $1 \mathrm{~mm}, 13 \mathrm{~mm}$ and $1000 \mathrm{~mm}$ respectively. $400 \mathrm{~mm}$ of the $1000 \mathrm{~mm}$ length is designed as the evaporator, $400 \mathrm{~mm}$ as the condenser and the remaining $200 \mathrm{~mm}$ as adiabatic section. There are 10 thermocouples in total (4 in the evaporator part, 4 in the condenser part and 2 in the coolant outlet and inlet). General view and schematic drawing of the test rig is given in Figure 5.
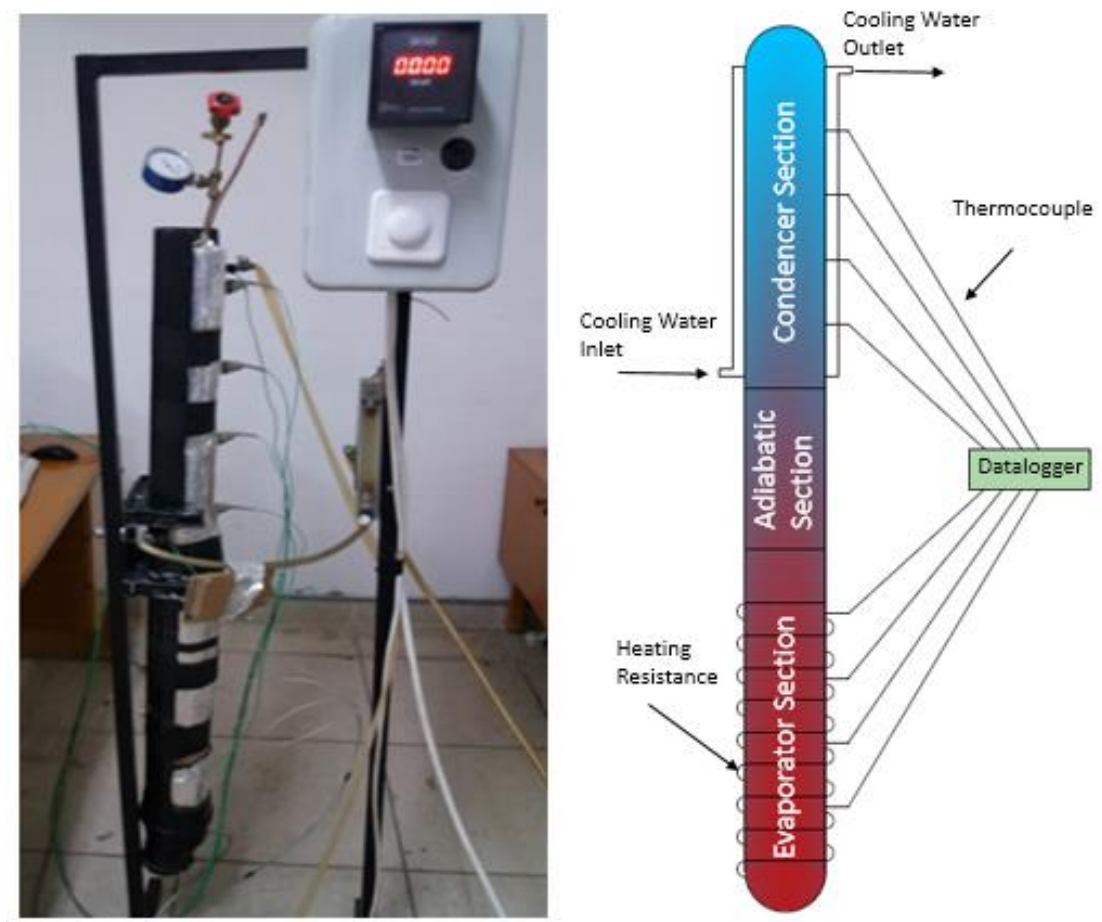

Figure 5: General view and schematic drawing of the test rig

The evaporator section is heated by a resistance whose power can be adjusted with a wattmeter. The working fluid evaporates in evaporator side. There isn't any heat transfer in adiabatic zone. Condenser side of the heat pipe is cooled down by water and the fluid condensates here. Condensing fluid goes back to evaporator section by gravity affect. This cycle goes on so long as the evaporator is heated and the condenser is cooled. Since thermosyphons work with the effect of gravity, they work more efficiently in upright or near vertical positions. Before starting the experiments, the interior of the heat pipe was vacuumed and all the air inside was evacuated and a negative pressure was created. Thanks to the 
negative pressure inside the pipe, the working fluid boils at a temperature lower than its boiling point at atmospheric pressure. Hence, the heat pipe will operate at lower temperatures. After vacuuming, $44 \mathrm{ml}$ of fluid was charged to the heat pipe. This number corresponds to $33 \%$ of the heat pipe. In an attempt to utilize the performance of the system under different operating conditions, experiments were repeated at three heating power and three coolant flow rates. Each experimental condition was made in triplicate and the average of the obtained values was used in the analysis of the system.

\subsection{Calculations}

Thermal performance of the pipe is evaluated by using efficiency, thermal resistance and heat pipe temperature distribution. These values were figured out for both pure water and $\mathrm{Fe} /$ water nanofluid, and the results were presented in graphs. The efficiency of the heat pipe is figured out with Eq 1 . Here, $\mathrm{Q}^{\circ} \mathrm{k}$ is the energy transferred to the coolant circulated in the condenser side of the heat pipe and is calculated with the help of equation 2. $\mathrm{Q}_{-} \mathrm{e}$ is the power consumed by the resistance in the evaporator side of the heat pipe $(150 \mathrm{~W}, 300 \mathrm{~W}, 450 \mathrm{~W})$.

$$
\begin{aligned}
& \eta=\frac{\dot{Q}_{k}}{\dot{Q}_{e}} \\
& \dot{Q}_{k}=\dot{m}_{\text {water }} c_{p, \text { water }}\left(T_{\text {outlet }}-T_{\text {inlet }}\right)
\end{aligned}
$$

The expressions $\mathrm{m}_{-}$su ,c_(p,su) and $\mathrm{T}$ in Equation 2 show the mass flow rate, specific heat and temperatures of the coolant, respectively.

The thermal resistance of the heat pipe is figured out with Eq 3. Here $\Delta \mathrm{T}$ is the average temperature difference between the evaporator and condenser parts of the heat pipe, and is found by Eq 4.

$$
\begin{aligned}
& R=\frac{\Delta T}{Q_{e}} \\
& \Delta T=\left(\frac{T_{1}+T_{2}+T_{3}+T_{4}}{4}\right)_{e}-\left(\frac{T_{1}+T_{2}+T_{3}+T_{4}}{4}\right)_{k}
\end{aligned}
$$

The temperature expressions in Eq 4 show the temperature values read from each thermocouple.

The improvement rate obtained by using nanofluid was found with the help of Eq 5.

$$
I R=\frac{\eta_{\text {nanofluid }}-\eta_{\text {pure water }}}{\eta_{\text {pure water }}} * 100
$$

\section{RESULTS AND DISCUSSION}

One of the most significant performance indicators of a heat pipe is thermal efficiency. To observe how the use of nanofluid in place of pure water affects the thermal efficiency of the heat pipe, the experiments were performed first by using pure water and then using $\mathrm{Fe}+$ Pure water nanofluid under the same conditions. The efficiency values calculated for both working fluids are given graphically in Figure 6 . When the graphs are examined, it is seen that the efficiency values are higher when Fe + pure water nanofluid was used in place of pure water. According to these graphs, increasing of coolant flow rate has also increased thermal efficiency. When the powers were $150 \mathrm{~W}$ and $300 \mathrm{~W}$, the maximum improvement rates were achieved for $6 \mathrm{~g} / \mathrm{s}$ water mass flow rate. When the heating power was $450 \mathrm{~W}$, the maximum improvement rate was achieved for $3 \mathrm{~g} / \mathrm{s}$ coolant flow rate. The increasing of heating power caused a slight decrease in thermal efficiency. According to the graph, the highest efficiency was reached as $77.9 \%$ in the experiment where Fe + Water nanofluid was used, the heating power was $150 \mathrm{~W}$ and the coolant flow rate was $9 \mathrm{~g} / \mathrm{s}$. Highest improvement rate was obtained as $50.3 \%$ at $450 \mathrm{~W}$ heating power and $3 \mathrm{~g} / \mathrm{s}$ water flow rate. However, the efficiency values obtained in this test were the lowest efficiency values for both fluids. 


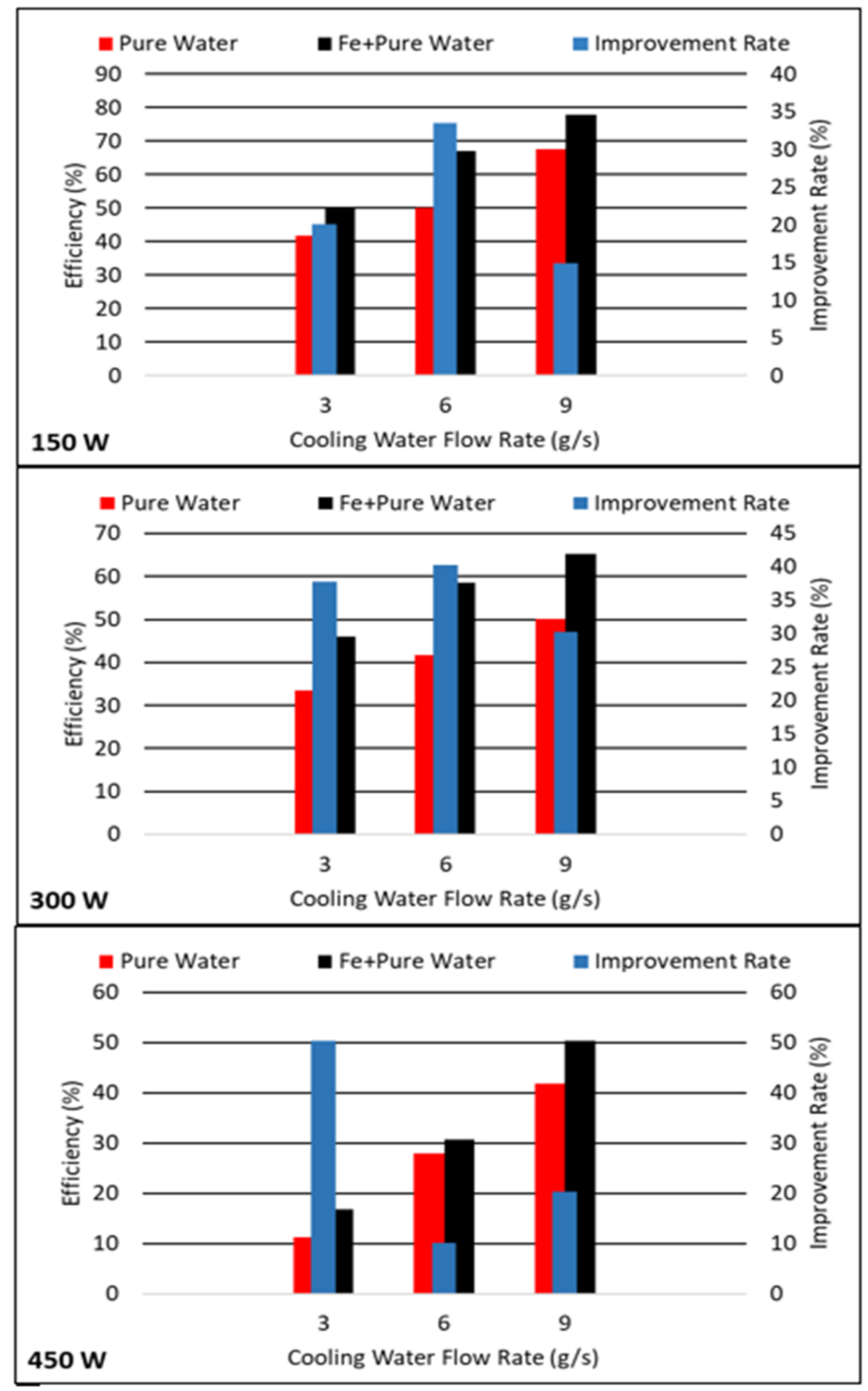

Figure 6: Efficiency of the heat pipe and improvement rates in efficiency 


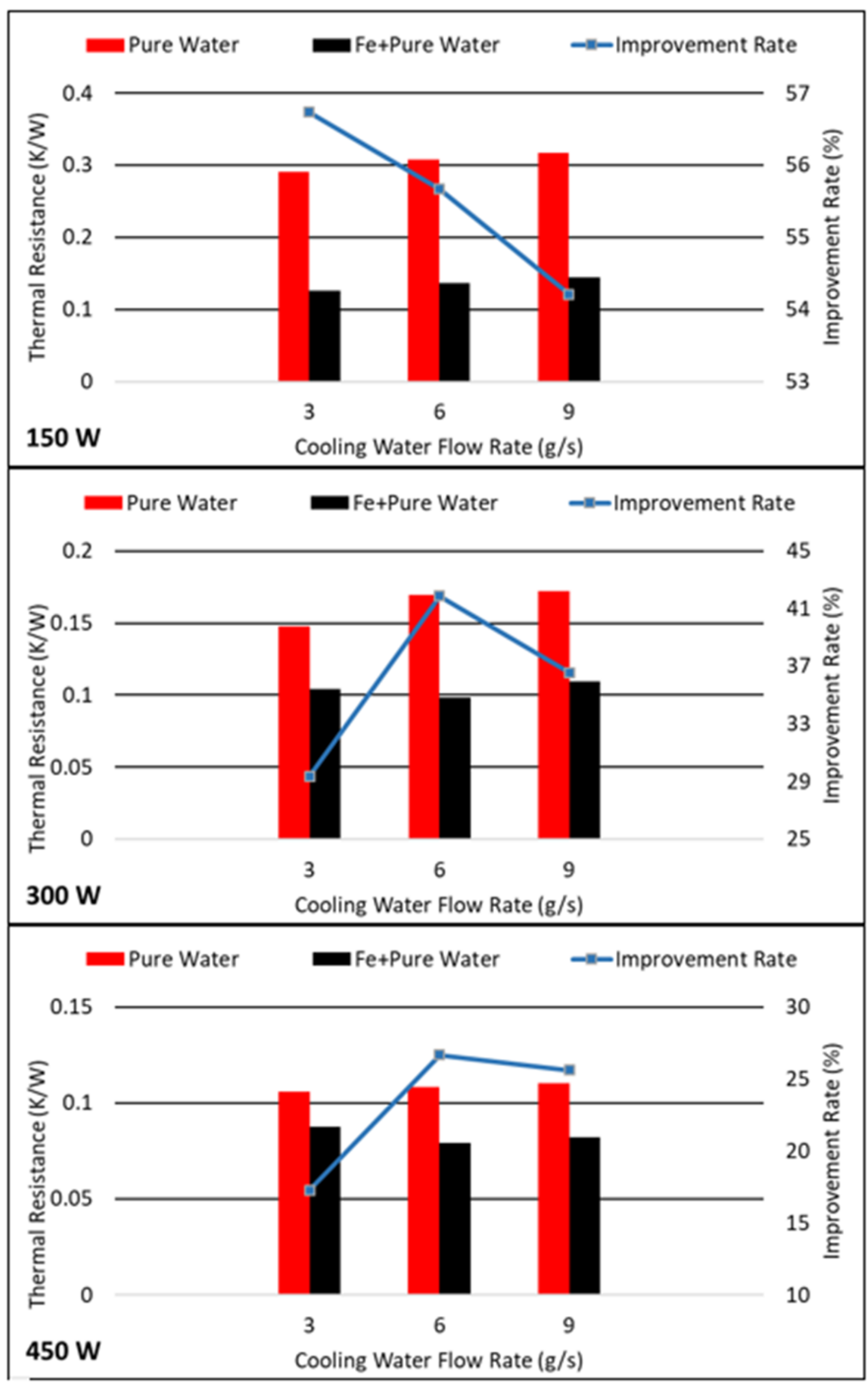

Figure 7: Thermal resistances and improvement rates 
One of the performance indicators is thermal resistances. The smaller thermal resistance, the higher energy transfer. It is aimed to reduce the resistance by using Fe + Pure water nanofluid. As can be seen from the graphs in Figure 7, by using Fe + Pure water nanofluid in place of water, a significant reduction in thermal resistances has been achieved. When the graphs are analyzed, it is seen that increasing of the heating power for both fluids provides some reduction in thermal resistances. The lowest resistance value has been reached as $0.0794 \mathrm{~K} / \mathrm{W}$ in the experiment using $\mathrm{Fe}+$ pure water nanofluid at $450 \mathrm{~W}$ heating power and $6 \mathrm{~g} / \mathrm{s}$ coolant flow rate. The highest reduction rate in thermal resistances was obtained as $56.7 \%$ at minimum conditions, i.e. $150 \mathrm{~W}$ heating power and $3 \mathrm{~g} / \mathrm{s}$ coolant flow rate. When the working fluids are examined separately, it is seen that the change of the coolant flow rate for each power value does not cause an excessive change in the thermal resistances. For example, in the experiment using $\mathrm{Fe}+$ pure water nanofluid with $150 \mathrm{~W}$ heating power, the thermal resistances obtained at $3 \mathrm{~g} / \mathrm{s}, 6 \mathrm{~g} / \mathrm{s}$ and $9 \mathrm{~g} / \mathrm{s}$ coolant flow rates are $0.1258 \mathrm{~K} / \mathrm{W}, 0.1367 \mathrm{~K} / \mathrm{W}$ and $0.1450 \mathrm{~K} / \mathrm{W}$, respectively. Under this condition, the decrease rates in thermal resistances were again $56.7 \%, 55.7 \%$ and $54.2 \%$, respectively.

Figures 8, 9 and 10 show the temperature distributions of the heat pipe wall at 150, 300 and $450 \mathrm{~W}$ heating powers, respectively. These graphs show how the temperature differences in the condenser and evaporator parts of the heat pipe change according to working fluid. The temperature differences seen here are taken into account when calculating the thermal resistance of the heat pipe. The use of $\mathrm{Fe}+\mathrm{Pure}$ water nanofluid in place of pure water did not cause much change in condenser temperatures, while it led to a significant decrease in evaporator temperatures. Assuming that the amount of heat given to the heat pipe in the evaporator is equal for both fluids, there is a greater heat transfer from the evaporator to the condenser when nanofluid is used, which made the temperature of the evaporator section lower. At equal condenser temperatures, lower evaporator temperatures mean lower thermal resistance. Also, as can be seen from the graphs, the increase in the coolant flow rate caused the condenser temperature to decrease. In other words, the amount of heat transferred to the water in the condenser section increased with the increase of the flow rate. This shows that the efficiency increases with the increase in flow rate. 


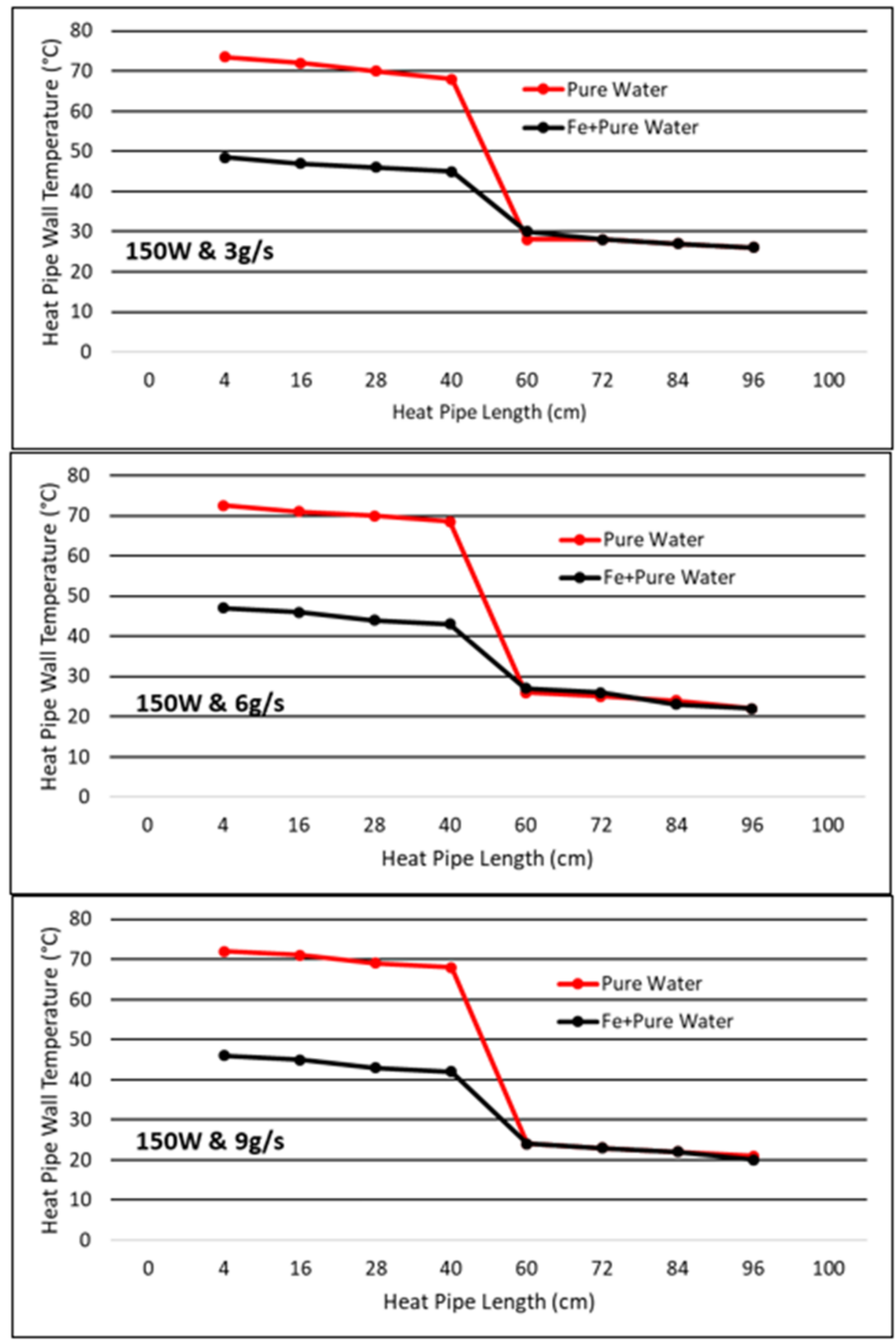

Figure 8: Heat pipe surface temperature distribution at 150 W heating power 


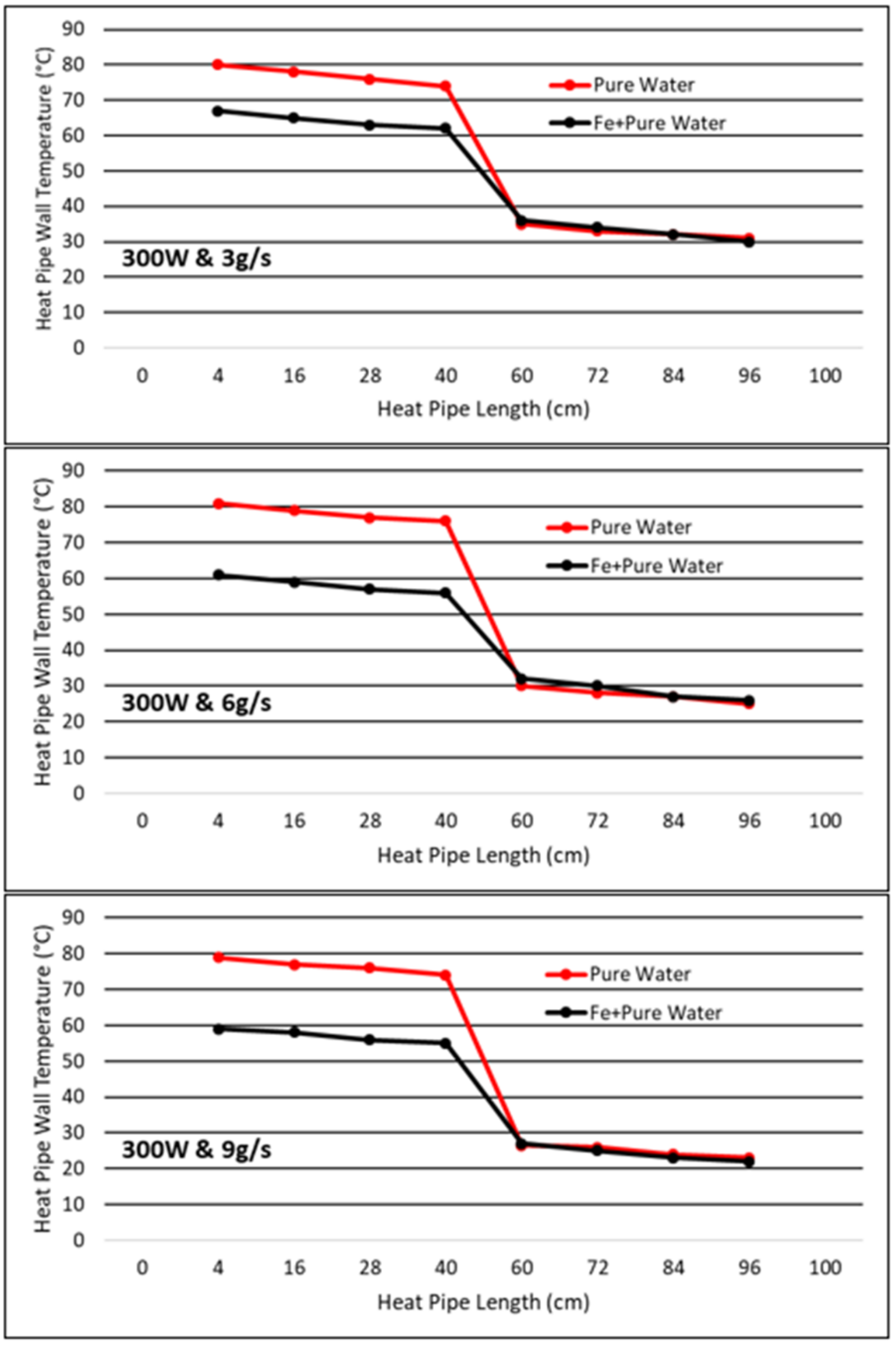

Figure 9: Heat pipe surface temperature distribution at 300 W heating power 


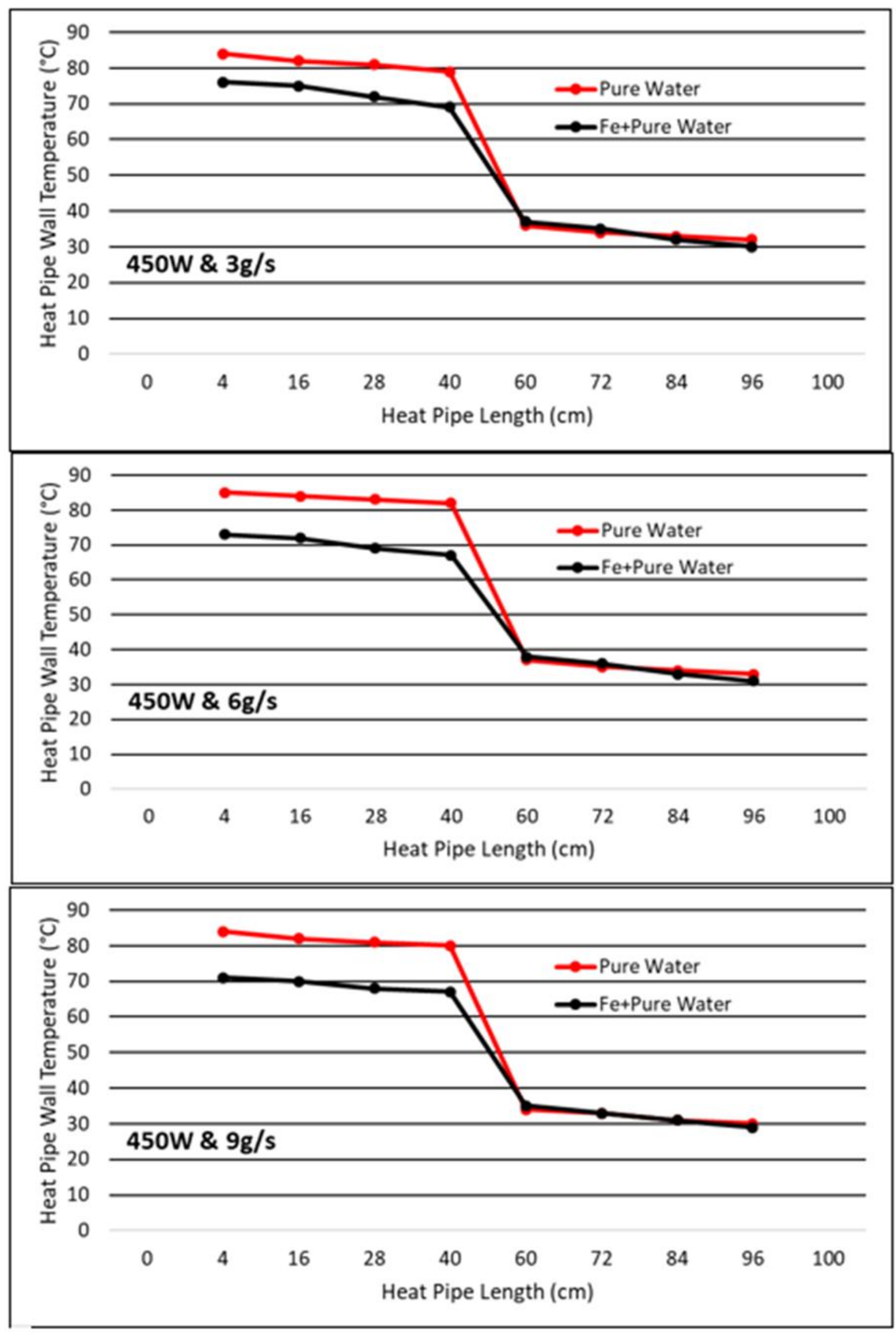

Figure 10: Heat pipe surface temperature distribution at 450 Wheating power 


\section{CONCLUSIONS}

In this experimental study, it was investigated how the use of nanofluids prepared with Fe nanoparticles, the base liquid of which is pure water, affects the thermal performance in a thermosyphon type two phase heat pipe. $0.2 \%$ by weight of surfactant and $1.5 \%$ by weight of nanoparticles were used in the nanofluid. In order to observe the performance of the heat pipe in different heating power and coolant flow rates and to determine the optimum operating conditions, the experiments at 3 different heating power and 3 different coolant flow rates were repeated using both pure water and $\mathrm{Fe}+$ Pure water nanofluid. According to the experimental results, the use of $\mathrm{Fe}+$ Pure water nanofluid in place of pure water had an increasing effect on the thermal performance of the heat pipe. It is possible to summarize the results of the experiment as follows;

- The usage of $\mathrm{Fe}+$ pure water nanofluid in place of pure water significantly increased the efficiency of the heat pipe under all experimental conditions. Maximum increasing rate in thermal efficiency was achieved as $\mathbf{5 0 . 3 \%}$ in the experiment conducted at $450 \mathrm{~W}$ heating power and $3 \mathrm{~g} / \mathrm{s}$ coolant flow rate.

- Again, the use of nanofluids in place of pure water provided a significant reduction in the thermal resistance of the heat pipe in all experimental conditions. The maximum reduction rate in thermal resistances was realized as $\mathbf{5 6 . 7} \%$ in the test performed at $150 \mathrm{~W}$ heating power and $3 \mathrm{~g} / \mathrm{s}$ coolant flow rate.

- The highest efficiency and lowest heat resistance values were reached in the experiment using $\mathrm{Fe}$ + Pure water nanofluid as $\mathbf{7 7 . 9 \%}$ and $0.0794 \mathrm{~K} / \mathrm{W}$, respectively.

- The highest thermal efficiency value was obtained at $150 \mathrm{~W}$ heating power and $9 \mathrm{~g} / \mathrm{s}$ coolant flow rate, while the lowest thermal resistance was obtained at $450 \mathrm{~W}$ and $6 \mathrm{~g} / \mathrm{s}$ coolant flow rate.

- Considering the heat pipe temperature distributions, it can be understood that the temperature formed in the evaporator is lower when nanofluid is used. This shows that a greater amount of heat transfer has taken place thanks to the nanofluid.

- In the evaluation made by considering the efficiency of the heat pipes, it is seen that the increase in the heating power causes a slight decrease in the efficiency. Increasing the coolant flow rate for the same power value also increased the efficiency values.

\section{NOMENCLATURE}

Fe: Iron nano particle

$\dot{\boldsymbol{Q}}_{\boldsymbol{k}}$ : The energy transferred to the coolant [W]

$\dot{\boldsymbol{Q}}_{\boldsymbol{e}}$ : The power consumed by the resistance [W]

$\dot{\boldsymbol{m}}$ : Mass flow rate of coolant $[\mathrm{g} / \mathrm{s}]$

$\boldsymbol{c}_{\boldsymbol{p}}: \quad$ Specific heat $[\mathrm{kJ} / \mathrm{kgK}]$

$\boldsymbol{\eta}$ : Efficiency

T: Temperature

$\Delta T:$ Average temperature difference between the evaporator and condenser

IR: Improvement Rate

$\boldsymbol{R}$ : Thermal Resistance 


\section{REFERENCES}

[1] Olabi, A.G., Elsaid, K., Sayed, E. T., Mahmoud, M. S., Wilberforce, T., Hassiba, R. J., \& Abdelkareem, M. A. (2020). Application of Nanofluids for Enhanced Waste Heat Recovery: A Review. Nano Energy, 105871. https://doi.org/10.1016/j.bjoms.2020.12.006

[2] Forman, C., Muritala, I. K., Pardemann, R., \& Meyer, B. (2016). Estimating the global waste heat potential. Renewable and Sustainable Energy Reviews, 57, 1568-1579. https://doi.org/10.1016/j.rser.2015.12.192

[3] Europan Comission. (2021). 2030 climate \& energy framework. Retrieved February 20, 2021, from https://ec.europa.eu/clima/policies/strategies/2030_en\#tab-0-0

[4] Ozsoy, A., \& Corumlu, V. (2018). Thermal performance of a thermosyphon heat pipe evacuated tube solar collector using silver-water nanofluid for commercial applications. Renewable Energy, 122, 2634. https://doi.org/10.1016/j.renene.2018.01.031

[5] Kaya, M., Gürel, A. E., Ağbulut, Ü., Ceylan, İ., Çelik, S., Ergün, A., \& Acar, B. (2019). Performance analysis of using $\mathrm{CuO}-$ Methanol nanofluid in a hybrid system with concentrated air collector and vacuum tube heat pipe. Energy Conversion and Management, 199(August). https://doi.org/10.1016/j.enconman.2019.111936

[6] Çiftçi, E. (2020). AlN/Saf Su Nanoakışkanının Isı Borusu Performans Parametreleri Üzerindeki Etkilerinin Deneysel Olarak Araştırılması. Gazi Üniversitesi Fen Bilimleri Dergisi Part C: Tasarım ve Teknoloji, 8(4), 858-871. https://doi.org/10.29109/gujsc.784306

[7] Wang, W. W., Cai, Y., Wang, L., Liu, C. W., Zhao, F. Y., Sheremet, M. A., \& Liu, D. (2020). A twophase closed thermosyphon operated with nanofluids for solar energy collectors: Thermodynamic modeling and entropy generation analysis. Solar Energy, 211(May), 192-209. https://doi.org/10.1016/j.solener.2020.09.031

[8] Khajehpour, E., Noghrehabadi, A. R., Nasab, A. E., \& Nabavi, S. M. H. (2020). Experimental investigation of the effect of nanofluids on the thermal resistance of a thermosyphon L-shape heat pipe at different angles. International Communications in Heat and Mass Transfer, 113(March), 104549. https://doi.org/10.1016/j.icheatmasstransfer.2020.104549

[9] Gallego, A., Herrera, B., Buitrago-Sierra, R., Zapata, C., \& Cacua, K. (2020). Influence of filling ratio on the thermal performance and efficiency of a thermosyphon operating with Al2O3-water based $\begin{array}{lllll}\text { nanofluids. Nano-Structures and } & \end{array}$ https://doi.org/10.1016/j.nanoso.2020.100448

[10] Vidhya, R., Balakrishnan, T., \& Suresh Kumar, B. (2020). Investigation on thermophysical properties and heat transfer performance of heat pipe charged with binary mixture based $\mathrm{ZnO}-\mathrm{MgO}$ hybrid nanofluids. Materials Today: Proceedings, (xxxx). https://doi.org/10.1016/j.matpr.2020.09.284

[11] Reji, A. K., Kumaresan, G., Sarathi, A., Saiganesh, A. G. ., Suriya Kumar, R., \& Shelton, M. M. (2020). Performance analysis of thermosyphon heat pipe using aluminum oxide nanofluid under various angles of inclination. Materials Today: Proceedings, (xxxx). https://doi.org/10.1016/j.matpr.2020.04.247

[12] Alagappan, N., \& Rathnasabapathy, C. S. (2019). Performance of Two Phase Copper Thermosyphon Operated with Cerium IV Oxide and Iron II, III Oxide Nano Fluid using BoxBehnken Design. Materials Today: Proceedings, 24, 2094-2107. https://doi.org/10.1016/j.matpr.2020.03.666 
[13] Sözen, A., Filiz, Ç., Aytaç, İ., Martin, K., Ali, H. M., Boran, K., \& Yetişken, Y. (2021). Upgrading of the Performance of an Air-to-Air Heat Exchanger Using Graphene/Water Nanofluid. International Journal of Thermophysics, 42(3). https://doi.org/10.1007/s10765-020-02790-w

[14] Nanografi Nano Teknoloji A.Ş. Retrieved May 28, 2021, from nanografi.com.tr

[15] Ali, H. M. (2020). Hybrid Nanofluids for Convection Heat Transfer.

[16] Khedkar, R. S., Sonawane, S. S., \& Wasewar, K. L. (2014). Heat transfer study on concentric tube heat exchanger using TiO2-water based nanofluid. International Communications in Heat and Mass Transfer, 57, 163-169. https://doi.org/10.1016/j.icheatmasstransfer.2014.07.011

[17] Sözen, A., Gürü, M., Menlik, T., Karakaya, U., \& Çiftçi, E. (2018). Experimental comparison of Triton X-100 and sodium dodecyl benzene sulfonate surfactants on thermal performance of TiO2deionized water nanofluid in a thermosyphon. Experimental Heat Transfer, 31(5), 450-469. https://doi.org/10.1080/08916152.2018.1445673

[18] Sezer, N., Atieh, M. A., \& Koç, M. (2019). A comprehensive review on synthesis, stability, thermophysical properties, and characterization of nanofluids. Powder Technology, 344, 404-431. https://doi.org/10.1016/j.powtec.2018.12.016 